\title{
EFFECTIVENESS RESEARCH ON A WAVY LAMELLAR PLATE-TYPE BIOFILTER WITH A CAPILLARY SYSTEM FOR THE HUMIDIFICATION OF THE PACKING MATERIAL APPLYING INTROINDUCED MICROORGANISMS
}

\author{
Kęstutis MAČAITIS ${ }^{\mathrm{a}}$, Antonas MISEVIČIUS ${ }^{\mathrm{b}}$, Algimantas PAŠKEVIČIUS ${ }^{\mathrm{c}}$, \\ Vita RAUDONIENE' $\dot{e}^{\mathrm{d}}$ Jūratė REPEČKIENE் \\ ${ }^{a, b}$ Environmental Institute, Vilnius Gediminas Technical University, \\ Sauletekio al. 11, LT-10223 Vilnius, Lithuania \\ c. d, eNature Research Centre, Vilnius University, Akademijos g. 2, LT-08412 Vilnius, Lithuania
}

Submitted 13 Jun. 2014; accepted 30 Sep. 2014

\begin{abstract}
To conduct research, a new generation plate-type air treatment biofilter for removing gaseous pollutants from air has been applied under laboratory conditions. A distinguishing feature of the packing material of the biofilter includes wavy lamellar polymer plates placed to each other and producing a capillary effect of humidification. While having such an arrangement, wavy lamellar plates also have rather wide spacing $(6 \mathrm{~mm})$, and therefore the employment of the structure of the plate-type packing material decreases the aerodynamic resistance of the device. A wavy porous plate is made of a polymer plate that ensures stiffness. Both sides of the wavy lamellar polymer plate have attached steam exploded birch fiber pellets under which, to increase plate capillarity, not-woven caulking material is put. This technological decision allows effectively enhancing the durability of the biopacking material. The work presents the results of research on the efficiency of the biodestruction process of acetone, xylene and ammonia. With reference to the conducted investigation, the high efficiency of air treatment and microbiological activity has been established. When pollutant gases (acetone, xylene and ammonia), under a velocity of $0.08 \mathrm{~m} \mathrm{~s}^{-1}$, passed through the biopacking material, microbiological activity in the material reached on average $1 \times 10^{8} \mathrm{cfu} / \mathrm{cm}^{2}$, and air treatment efficiency made $90.7 \%$.
\end{abstract}

Keywords: biofilter, air treatment efficiency, capillary, biopacking material, microorganisms.

\section{Introduction}

The branches of industry like chemistry, varnishes and paints, food and oil refining terminals use a large amount of chemical materials that find different ways to be released into the atmosphere. Acetone, butanol, toluene, xylene, ammonia methane, etc. are among the most common volatile organic and inorganic compounds emitted to the atmosphere due to human factors and forming photochemical antioxidants, a high concentration of which is harmful to human health, plants and the environment in general (Baltrènas et al. 2004; Jeong et al. 2006; Paulauskienè et al. 2011).

The emission levels of volatile organic compounds (acetone, xylene) to the atmosphere are significantly lower than those of combustion products, for example, $\mathrm{CO}_{2}, \mathrm{CO}$, $\mathrm{SO}_{2}$ and $\mathrm{NO}_{2}$. However, the impact of VOC on humans and the natural environment is much stronger (PielechPrzybylska et al. 2006; Paulauskienè et al. 2011; Yang et al. 2010). Also, the increasing amounts of VOC directly influence fluctuations in climate and are related to the depletion of the ozone layer (Delhomenie, Heitz 2005). Thus, the decontamination of these pollutants is an important task leading a reduction in a negative impact on the environment.

VOC (acetone, xylene) and ammonia are most frequently emitted from wastewater treatment plants in a number of industries such as foundries, chemical industry, electronics, paints, etc. (Wu et al. 2006; Jun, Wenfeng 2009).

At the moment, biological air treatment using certain cultures of microorganisms is one of the most promising air cleaning methods (Baltrènas, Zagorskis 2009).

Corresponding author: Kęstutis Mačaitis

E-mail: kestutis.macaitis@vgtu.lt 
Biofilters are employed for removing butanol, acetone, xylene, toluene and other volatile organic compounds from air. Equipment may be efficient when the concentration of the pollutant does not exceed $500 \mathrm{mg} / \mathrm{m}^{3}$ (Baltrenas, Zagorskis 2010).

The effectiveness of the biological air treatment process depends on the growth of microorganism cultures in the medium. At the initial moment of air treatment, under a continuous supply of pollutants to the biofilter and while activating microorganisms, they encounter surplus food and therefore grow (Domsh et al. 2007).

To initiate the biodestruction of pollutants in the biofilter and to stimulate the development of microorganisms, appropriate conditions are required. Physical factors such as humidity and temperature often affect the growth and reproduction of microorganisms (Baltrenas et al. 2004). Water, in this case, is the most powerful medium where the metabolism reactions of materials take place; moreover, all chemical reactions occurring in live microorganisms necessitate water that makes approximately $75 \%$ and even more of the whole biomass (Zigmontiene, Žarnauskas 2011).

The fundamental element of the biological air treatment device is a filtering medium necessary as substrate for microorganisms, and at the same time, providing them with the needed nutrients. In practice, as the filtering media, the packing materials of natural origin, including compost, peat, wood chips, bark and activated sludge, are applied (Zigmontiené, Baltrènas 2004).

The humidification systems arranged in biofilters have a strong impact on the efficiency of biological air treatment (Mohseni, Allen 2000; Shareefdeen et al. 2003). The optimal humidity of the packing material is $60-80 \%$. At present, the applied biofilters use the humidified packing material employing the above placed humidification nozzles, water to which is supplied to the pump from a water tank. While applying the introduced humidification system, a large amount of electricity is used, anaerobic areas occur inside the filtering layer and a possibility of leaching biomass from the packing material arises, which causes a decrease in the efficiency of biofilters used for air treatment. In the events of electricity failure or the crash of the technological process, the packing material is not humidified and therefore may parch or cracks may appear.

The humidity of the packing material depends on the type of the material and the humidification system installed into the biofilter. In our researched case, the biofilter contains the implemented capillary system for the humidification of the packing material, i.e. the medium in the biofilter, due to narrow spacing $(6 \mathrm{~mm})$ between wavy lamellar plates, has risen with the help of not-woven caulking material and birch fiber pores.

One of the main requirements for biological air treatment equipment are the low aerodynamic resistance of the packing material. Aerodynamic resistance depends on a variety of factors like the porosity, form, fraction and humidity of the packing material. The aerodynamic resistance of the packing material also affects the treatment efficiency of the biofilter (Eldon et al. 2010). Lower aerodynamic resistance determines a better distribution of oxygen, which is involved in the metabolic processes of nutrients, in the packing material. Regular search for the methods that improve the aerodynamic processes occurring in the packing material without reducing the effectiveness of treatment is taking place (Baltrènas, Zagorskis 2009).

Time for contact between the biopacking material and pollutant seems to be an important aspect of optimal and efficient air treatment. The lower is the air flow rate in the biofilter, the longer takes time for contact between the polluted air and the used packing material, which therefore increases the effectiveness of the biodestructive process.

Temperature is a crucial factor having an influence on the proliferation of microorganisms and on the intensiveness of biochemical reactions. Different groups of microorganisms have adapted for living under different temperatures. The microorganisms involved in the processes of pollutant biodestruction fall into a few categories, including psychrophilic, mesophilic and thermophilic. Research was conducted under a temperature of $25-30{ }^{\circ} \mathrm{C}$ in the medium and air in the biofilter. The maintained temperature was favourable for the growth and development of mesophilic microorganisms (Boswell 2010).

The conducted investigation has been aimed at using a capillary system for the humidification of the packing material made of porous wavy lamellar plates so that to establish the efficiency of the biofilter while emitting the air polluted with acetone, xylene and ammonia emissions and propagating introinduced microorganisms.

\section{Research methods}

\subsection{Structure of the Biofilter}

To conduct research, a bench of a laboratory biofilter has been employed (Fig. 1). The biofilter stands out for completely new design that allows reducing the aerodynamic resistance of the device, and the capillary system for humidifying the packing material improves the qualities of humidity retention in the packing material as well as decreases energy expenses.

The packing material of the biofilter uses wavy lamellar plates which, while moving in the contaminated air flow, increase contact between the employed pollutants and wavy lamellar partition walls containing microorganisms.

The structure of the biofilter consists of the biopacking material (cassette has been made of wavy lamellar 


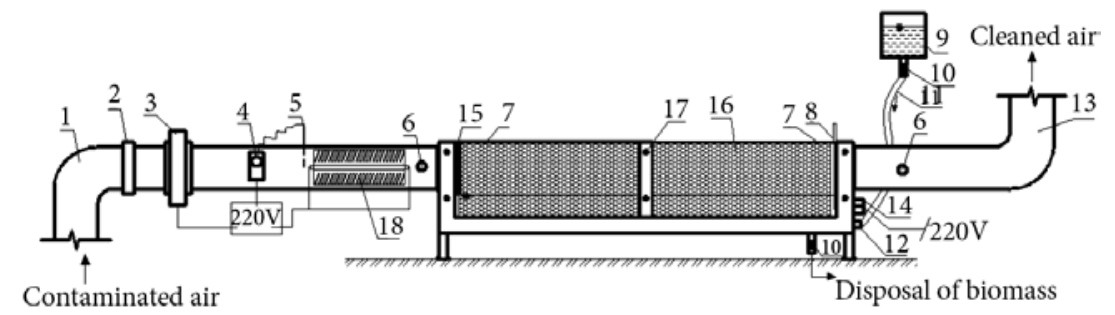

Fig. 1. Scheme for a wavy lamellar plate-type air treatment biofilter with a capillary system for the humidification of the packing material

plates), the system for maintaining the humidity and temperature of the packing material in the filter (air heater with a control thermostat and sensor; heating element of the bio-medium), ventilator (maintains a constant air flow rate in the packing material of the biofilter), air ducts for supplying and removing air from the device, air flow control valve (the adjustable air flow rate and, simultaneously, the supplied air rate), perforated card (evenly distributes air flow over the total volume of the packing material) and drain valve (excess biomass is removed from the biofilter).

The operation principle of the lab biofilter (Fig. 1) refers to the packing material in which microorganisms decompose gaseous emissions to $\mathrm{CO}_{2}$ and $\mathrm{H}_{2} \mathrm{O}$. The polluted air is supplied to the biofilter through the air duct $100 \mathrm{~mm}$ in diameter (1). Air flow moves through the biofilter because of the ventilator arranged in the air duct for supplying the polluted air (3). The valve (2) is placed in the air duct of the polluted air and adjusts air flow and

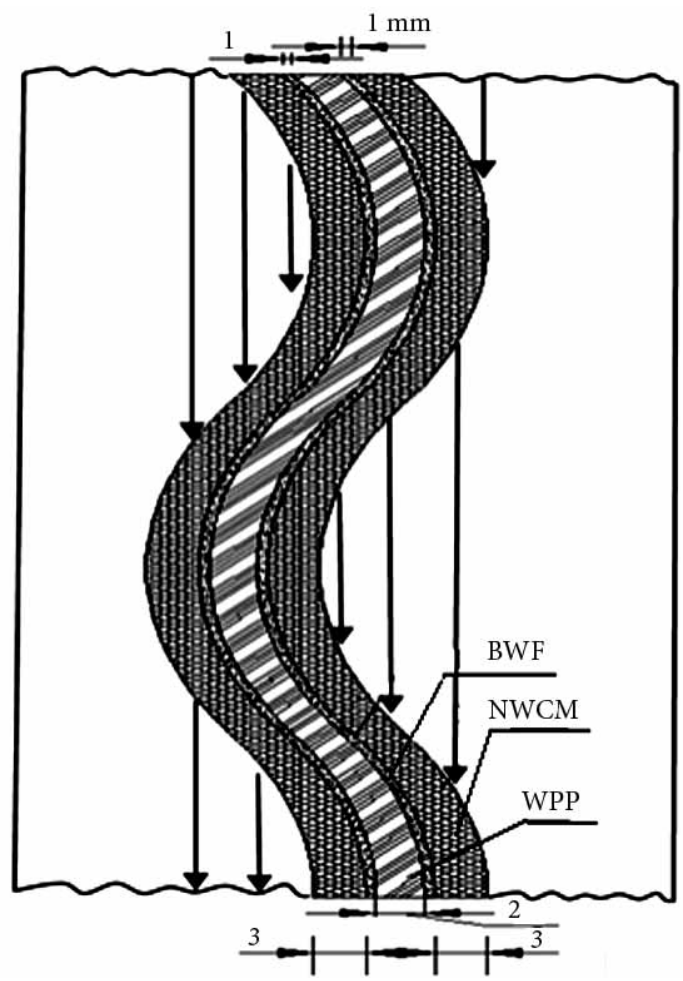

Fig. 2. The structure of the porous plate (WPP - wavy lamellar polymer plate, BWF - birch wood fiber, NWCM - not-woven caulking material); air flow direction supplied air rates. Next, the polluted air flow reaches the cassette of the biofilter (16) charged with the packing material made of porous plates. The perforated plate (15) is used for evenly distributing air flow throughout the total volume of the packing material. The polluted air moves between porous plates immersed in a liquid medium and placed in $4 \mathrm{~mm}$ apart. The purified air stream passes through the cassette of the biofilter (16) charged with the packing material, reaches the purified air duct $100 \mathrm{~mm}$ in diameter and is removed to the environment. The cassette is attached to the device with the help of fasteners (7). The ducts of the polluted and purified air have installed sample slots (6). These places have the established air flow rate and temperature as well as the concentrations of pollutants supplied to and removed from the biofilter. The excess biomass is removed from the biofilter through the drain valve of the biomass (10). The required temperature of the supplied air flow is supported by an air duct heater (18) equipped with a control thermostat and sensor $(4,5)$. The temperature of the bio-medium is maintained using the heating element (14). To supply a nutrient-rich solution to the biofilter, a tank with adjustable valves $(10,12)$ and a hose (11) have been installed.

The main element of the biofilter is a cassette made of wavy lamellar plates onto which the biopacking material, i.e. not-woven caulking material and wood fiber, is attached. The dimensions of the cartridge make $900 \times 200 \times 200 \mathrm{~mm}$.

The packing material consists of wavy porous plates vertically arranged next to each other and making a capillary humidifying effect of the packing material. Such an arrangement of the plates points to $6 \mathrm{~mm}$ spacing. The structure of the plates is shown in (Fig. 2).

Both sides of the wavy lamellar polymer plate have attached steam exploded birch fiber pellets. The steam explosion of birch fiber is necessary for maintaining its durability. Birch fiber is received through the steam explosion of birch sawdust in the reactor under the pressure of 32 bars and a temperature of $235^{\circ} \mathrm{C}$. Thus, changes in the chemical structure of wood prevent birch fiber from decay in a humid environment, and therefore the durability of the packing material of the biofilter increases. To enlarge the capillarity of the plate along with the uplift height of 
the bio-medium, not-woven caulking material is attached to birch fiber. The dimensions of the porous plate in the bio-filter make $900 \times 200 \times 10 \mathrm{~mm}$.

The relative and absolute humidity of materials has been established with reference to the weight based on a decrease in the amount of mass. Porosity has been found out with the help of saturation, whereas density - employing the weighing method.

Choosing materials has been determined by their inner structure. The composition of the material has been defined applying the method of electron microscopy. Scanning electron microscopy has been done using field emission scanning electron microscope JEOL ISM - $7600 \mathrm{~F}$ magnifying from 25 to 1000000 times. The accelerating voltage of electrons varied from $0,1 \mathrm{kV}$ to $30 \mathrm{kV}$. Image resolution was up to $5120 \times 3840$ pixels. The structure of the investigated materials is shown in (Fig. 3) and (Fig. 4).

\subsection{Maintaining humidity in the biofilter with a wavy lamellar structure}

The biofilter is immersed in a solution saturated with biogenic elements (Fig. 1). The solution used for research purposes has been made of $\mathrm{K}_{2} \mathrm{HPO}_{4}-1 \mathrm{~g}, \mathrm{KCl}-0.5 \mathrm{~g}$,
$\mathrm{MgSO}_{4} \times 7 \mathrm{H}_{2} \mathrm{O}-0.5 \mathrm{~g}, \mathrm{FeSO}_{4} \times 7 \mathrm{H}_{2} \mathrm{O}-0,1 \mathrm{~g}, \mathrm{NaNO}_{3}-$ $0.90 \mathrm{~g}$ and $1000 \mathrm{~g}$ distilled water (Baltrènas, Zagorskis 2009; Trejo-Aguilar et al. 2005; Liao et al. 2008; Chang, Lu 2003; Wright 2005; Dorado et al. 2008; Mansour et al. 2011).

The depth of the soaked porous plates reached $55 \mathrm{~mm}$. Due to the porous structure and spacing of wavy lamellar plates placed to each other within a distance of $6 \mathrm{~mm}$, the capillary effect of humidifying the packing material takes place. The humidity of the packing material is found using measuring device M0290, the operation principle of which is based on the method for measuring electrical resistance. The interval of calculating humidity varies from 0 to $99.9 \%$, and measurement error is $\pm 0.1 \%$.

\subsection{Establishing $\mathrm{pH}$ and temperature of the bio-medium}

The required $\mathrm{pH}$ and temperature of the solution (bio-medium) saturated with biogenic elements were maintained using buffer solutions (Baltrènas, Zagorskis 2010). $\mathrm{pH}$ was found out with reference to LST ISO 10523 standard. To set the necessary temperature and $\mathrm{pH}$, the Mettler Toledo
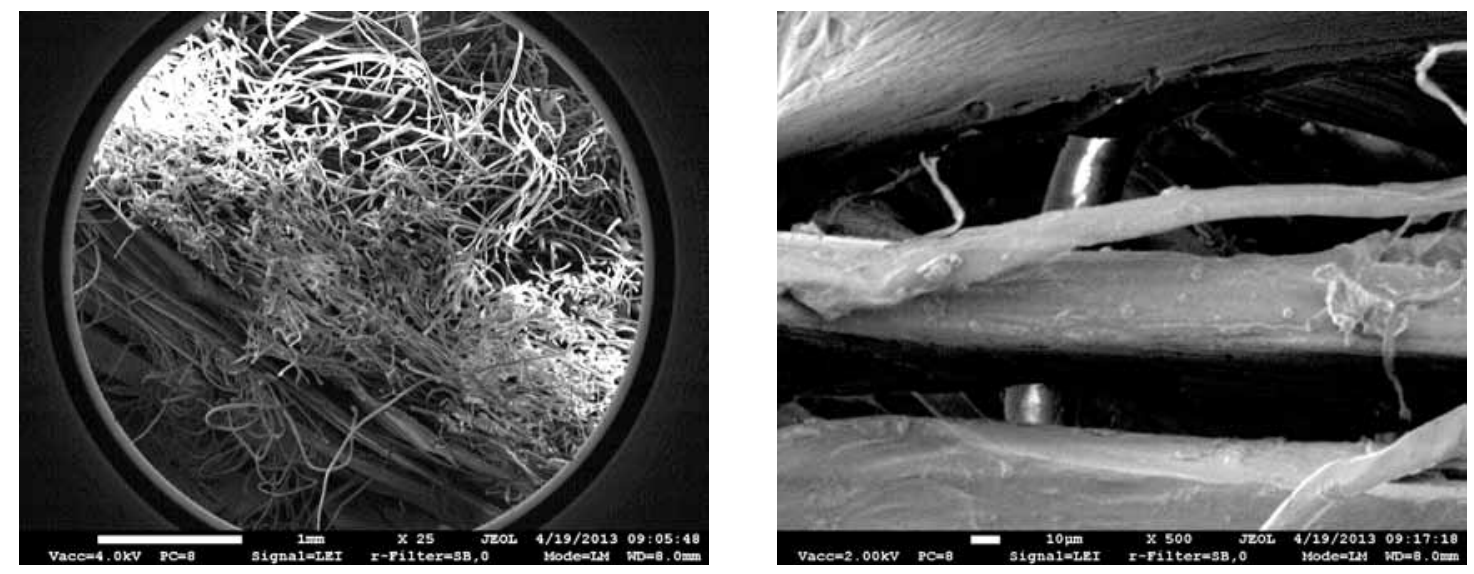

Fig. 3. The structure of not-woven caulking material, magnified 25 times (left) and 500 times (right)
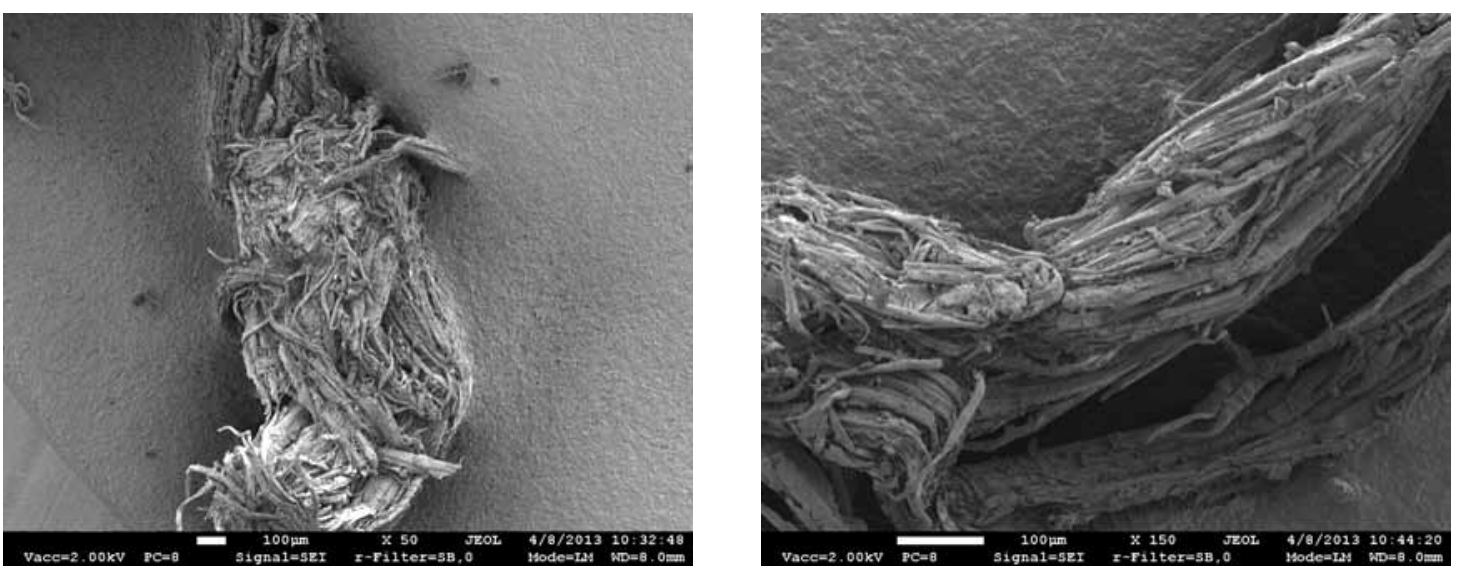

Fig. 4. The structure of birch wood fiber, magnified 50 times (left) and 150 times (right) 
measuring device was used. The measurement interval of the device is from 0 to 14 , and measurement error is \pm 0.01 . The records of $\mathrm{pH}$ index and temperature were displayed on a daily basis.

To preserve a constant temperature of $30^{\circ} \mathrm{C}$ in the bio-medium, a heating element of the bio-medium in the lower part of the biofilter was arranged. In order the air supplied to the biofilter should not cool down the biomedium on the packing material, the duct supplying pollutants has an installed channel heater ensuring a constant $30{ }^{\circ} \mathrm{C}$ temperature of the air flow supplied to the biofilter.

\subsection{Microbiological research}

To identify microorganisms and to calculate their quantity, the flush (suspension dilution) method (presented in the developed methodology) was used. From each sample, $1 \mathrm{~g}$-sized piece is weighed and placed in a flask with $90 \mathrm{ml}$ of $0.8 \% \mathrm{NaCl}$ where suspension procedures take place. To compare different samples with each other, calculations are done drying the specimen material to a constant weight, and then, the number of the microorganisms of $1 \mathrm{~g}$ of a dry weight of the biofilter material is defined. In addition, the area of the weighed piece is measured, and the number of microorganisms per $1 \mathrm{~cm}^{2}$ is calculated.

The composition of the nutrient agar includes water $-1000 \mathrm{~g}$, agar $-15.0 \mathrm{~g}$, peptone $-5.0 \mathrm{~g}, \mathrm{NaCl}-5.0 \mathrm{~g}$, yeast extract $-5.0 \mathrm{~g}$ and meat extract $-1 \mathrm{~g}$. Seeding takes place three times. Under a stagnant medium, the dish moves having a mix of the medium and suspension to make them uniformly spread at the bottom of the dish. At a later stage, Petri dishes, including microorganisms, are incubated in the thermostat.

Petri dishes with bacteria are incubated in the thermostat for 2-3 days and with micromycetes - 5-7 days at a temperature of $26-28{ }^{\circ} \mathrm{C}$. The colonies of micromycetes and bacteria are calculated figuring out the amount of rudiments in $1 \mathrm{~g}$ of the tested substance. The number of live cells is defined having multiplied the average number of colonies in the dishes and the coefficient of dilution.

Micromycetes were distinguished on the agarized beer wort. Seeds were incubated in Petri dishes under a temperature of $+28^{\circ} \mathrm{C}$ for $5-7$ days.

Pure cultures of micromycetes are identified employing classic methods with reference to the definitions of micromycetes (Chaverri, Samuels 2003; Samson, Frisvad 2004; Domsh et al. 2007; Pečiulyte, Bridžiuvienè 2008, etc.).

Yeast were distinguished on the nutrient media of Sabouraud agar with chloramphenicol (Liofilfem, Italy) and Rose Bengal CAF agar (Liofilchem, Italy). Seeds took place in Petri dishes at a temperature of $+28{ }^{\circ} \mathrm{C}$ for $3-4$ days.

Yeast were discovered applying Api 20 C AUX (bioMérieux, France) identification systems.
Bacillus cereus media were agarized. Crop prepared bacterial suspension included 1:10, 1:100, 1:1000, 1:10.000, $1: 100.000,1: 1.000 .000,1: 10.000 .000,1: 100.000 .000$, 1:1.000.000.000, 1:10.000.000.000.

The distinguished bacteria were identified according to their morphological and physiological properties and compared with data provided in literature. Bacteria were described according to Bergey's Manual of Systematic Bacteriology (Palleroni 1984; Garrity et al. 2005).

\subsection{Activating the packing material and establishing the efficiency of the biodestruction process}

The conducted research involved the air flow that passed through the packing material of the biofilter and was contaminated with acetone, xylene and ammonia vapours. The air flow rate between wavy lamellar plates reached, on average, $0,08 \mathrm{~m} / \mathrm{s}$ and was established and observed on a daily basis applying precision humidity measuring instrument Testo 400 with a thermocouple, the precision of the measurements of which, under the air flow rate from $0 \mathrm{~m} / \mathrm{s}$ to $2 \mathrm{~m} / \mathrm{s}$, makes $\pm 0.01 \mathrm{~m} / \mathrm{s}$.

The initial concentration of pollutants reaches, on average, $5.7 \mathrm{mg} / \mathrm{m}^{3}$. The device was supplied with acetone vapour for 15 minutes 4 times a day. The next day, the concentration of the organic compound was increased $20 \pm 5 \mathrm{mg} / \mathrm{m}^{3}$ thus extending the delivery time of acetone vapour up to 1 hour. The research on supplying the air polluted with acetone vapour took 15 days. Afterwards, the pollutant was replaced with xylene, and investigation was carried on gradually increasing the concentration of acetone vapour delivered to the biofilter. The study on emitting the air polluted with xylene vapour took 5 days. Upon the completion of research on xylene, the air contaminated with ammonia vapours passed through the packing material. Investigation into ammonia lasted for 6 days.

The efficiency of pollutant biodegradation is calculated having found the concentration of the pollutant before and following the treatment device. Pollutant concentration is established with the help of portable VOC monitor MiniRae 2000, the measurement limits of which are in the range from 0 to $7000 \mathrm{mg} / \mathrm{m}^{3}$. Measurement accuracy, when pollutant concentration is in the range from 0 to $100 \mathrm{mg} / \mathrm{m}^{3}$, makes $0.1 \mathrm{mg} / \mathrm{m}^{3}$, and when pollutant concentration exceeds $100 \mathrm{mg} / \mathrm{m}^{3}-1 \mathrm{mg} / \mathrm{m}^{3}$.

\section{Results and discussion}

The biopacking material is one of the basic elements of the biofilter. A crucial point before conducting investigation is the formation of the packing material upon which the physical qualities of the packing material depend and determine the efficiency of the biodegradation process. In this case, the porosity of the packing material and 
capillary play a leading role. It has been established that a higher porosity of the material causes better absorption of pollutants from the contaminated air (Beyaz et al. 2010). Herewith, a higher porosity of the material makes the capillary humidification of the packing material more effective. Due to a higher porosity of the packing material and effective capillary, the biodegradation process becomes more efficient.

Investigation into the structure of materials has revealed that the major part of not-woven caulking material is made from small filaments of 15 to $25 \mu \mathrm{m}$ thick. The spaces between the filaments are 5 to 10 times larger than the thickness of the filaments themselves (Fig. 3, left). Such filament distribution allows making a biofilm thus avoiding anaerobic zones harmful to microorganisms. Chaotic filament distribution allows increasing the specific surface area of the material and the volume of the bio-medium in the material. The picture of the material magnified up to 500 times displays the filaments of $120-180 \mu \mathrm{m}$ thick making the capillaries of 10-30 $\mu \mathrm{m}$ thick (Fig. 3, right). Steam exploded birch fiber also has an irregular surface, porous structure, and thus a higher specific surface area (Fig. 4). As indicated, birch wood fiber is made of like the many tiny "straws" arranged in parallel to each other and reaching $15-30 \mu \mathrm{m}$ thick. Wood fiber in the packing material is required so that the microorganisms in the biomedia should take up organic carbon that is in the fiber.

Before starting the exploitation of biological air treatment equipment, the installed biopacking material is biologically activated emitting it through the air contaminated with organic pollutants (Baltrenas et al. 2004). The biologically activated packing material is fully accepted as such when covered with a thin layer of the biofilm (5-30 $\mu \mathrm{m}$ thick) with a population of microorganisms. In this case, the packing material was activated up to the $10^{\text {th }}$ day of the experiment. The packing material was activated supplying acetone to the polluted air thus increasing the concentration of acetone and monitoring the treatment efficiency of the biofilter.

Fig. 5 shows that the air treatment efficiency of the biofilter increased up to the $10^{\text {th }}$ day of the experiment. This is exactly the time when the highest established treatment efficiency reached $94.7 \%$, which was caused by a growing amount of bacteria up to $(1.0 \pm 0.2) \times 10^{10} \mathrm{cfu} / \mathrm{cm}^{2}$. The initial acetone concentration before treatment made $25 \mathrm{mg} / \mathrm{m}^{3}$, whereas at the end of the experiment it reached $700 \mathrm{mg} / \mathrm{m}^{3}$.

On the $10^{\text {th }}$ day, $220 \mathrm{mg} / \mathrm{m}^{3}$ acetone vapour concentration was supplied to the biofilter. Under the pollutant concentration of $300 \mathrm{mg} / \mathrm{m}^{3}$, the air treatment efficiency of the biofilter made $93.4 \%$.

Later, a growth in the amount of pollutant concentration in air up to $500 \mathrm{mg} / \mathrm{m}^{3}$ reduced the air treatment efficiency of the biofilter to $86 \%$. On the $16^{\text {th }}$ day of the conducted investigations, the concentration of acetone was increased to $700 \mathrm{mg} / \mathrm{m}^{3}$, which resulted in the treatment efficiency of $84 \%$.

The analysis of the below chart showing the treatment efficiency of acetone demonstrates that, under steady analysis (starting from the $10^{\text {th }}$ day of the experiment), treatment efficiency was higher than $80 \%$.

The average amount of bacteria after the $10^{\text {th }}$ day of research was $(6.8 \pm 0.2) \times 10^{8} \mathrm{cfu} / \mathrm{cm}^{2}$, yeast - $(3.8 \pm$ $0.4) \times 10^{6} \mathrm{cfu} / \mathrm{cm}^{2}$ and micromycetes $-(3.2 \pm 0.6) \times 10^{7} \mathrm{cfu} \mathrm{cm}^{2}$.

Study was carried out under the treated air flow and made $1.08 \mathrm{l} / \mathrm{s}$. Time for contact between the packing material and the polluted air reached $11.39 \mathrm{~s}$.

A comparison of the research findings of other scientists such as Chang and $\mathrm{Lu}$ (2003) who investigated the air contaminated with acetone vapour and the results of our examination demonstrate that treating efficiency reaches from $80 \%$ to $85 \%$, and the concentration of acetone vapour in the supplied air makes from $175 \pm 10 \mathrm{mg} / \mathrm{m}^{3}$ to $700 \pm 35 \mathrm{mg} / \mathrm{m}^{3}$. In our case, the treatment efficiency of $80 \%$ is available when the concentration of acetone in air gets to $\sim 600 \mathrm{mg} / \mathrm{m}^{3}$.

Fig. 6 shows that treatment efficiency within the biodestruction process of xylene in all days of the performed investigation reached more than $80 \%$. The initial pollutant

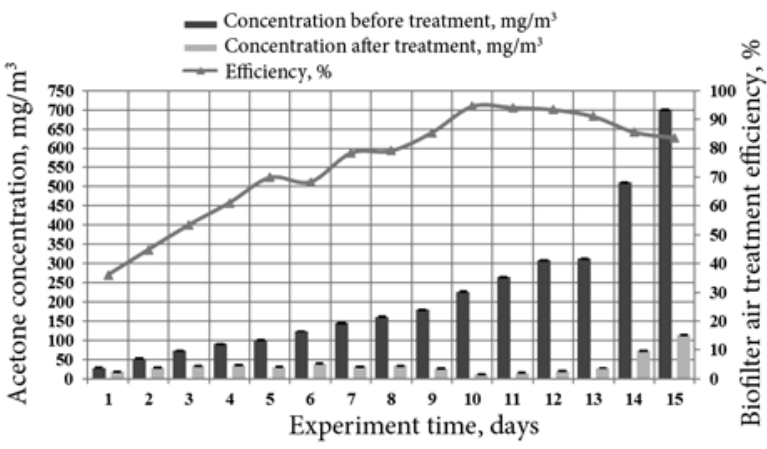

Fig. 5. Acetone concentration before and after treatment $\left(\mathrm{mg} / \mathrm{m}^{3}\right)$ and the efficiency of biofilter treatment under the application of wavy lamellar plates and the packing material made of wood fiber and not-woven caulking material

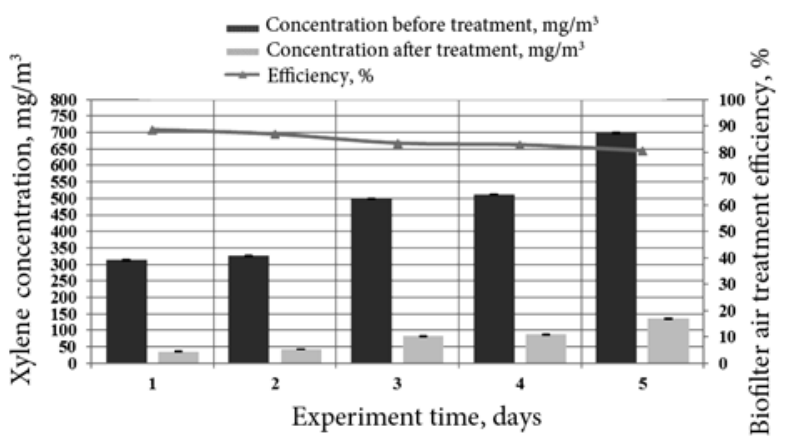

Fig. 6. Xylene concentration before and after treatment $\left(\mathrm{mg} / \mathrm{m}^{3}\right)$ and the efficiency of biofilter treatment under the application of wavy lamellar plates and the packing material made of wood fiber and not-woven caulking material 
concentration before treatment was $313 \mathrm{mg} / \mathrm{m}^{3}$, whereas at the end of the experiment $-699 \mathrm{mg} / \mathrm{m}^{3}$. Fig. 6 also demonstrates that the air treatment efficiency of the biofilter, under the pollutant concentration of $300 \mathrm{mg} / \mathrm{m}^{3}\left(1^{\text {st }}\right.$ day of research), achieved $87.7 \%$, under a concentration of $500 \mathrm{mg} / \mathrm{m}^{3}$ ( $3^{\text {rd }}$ day of research $)-83.1 \%$ and under a concentration of $700 \mathrm{mg} / \mathrm{m}^{3}$ ( $5^{\text {th }}$ day of research $)-80.6 \%$.

An increase in pollutant concentration in the supplied air resulted in a gradual decrease of $3-4 \%$ in air treatment. A reduction of microorganisms in the packing material can also be attached to this phenomenon. At the beginning of the research, the average amount of bacteria was $(1.8 \pm 0.3) \times 10^{9} \mathrm{cfu} / \mathrm{cm}^{2}$, yeast $-(4.1 \pm 0.1) \times 10^{6} \mathrm{cfu} \mathrm{cm}^{2}$ and micromycetes $-(1.2 \pm 0,6) \times 10^{5} \mathrm{cfu} / \mathrm{cm}^{2}$, whereas at the end $\left(5^{\text {th }}\right.$ day of research) $-(4.6 \pm 0.0) \times 10^{8} \mathrm{cfu} / \mathrm{cm}^{2}$, yeast $-(2.2 \pm 0.1) \times 10^{5} \mathrm{cfu} / \mathrm{cm}^{2}$ and micromycetes $-(1.4 \pm$ $0.3) \times 10^{6} \mathrm{cfu} / \mathrm{cm}^{2}$. Japanese scientists Jeong et. al. (2008) also investigated the biofilter supplying it with the concentrations of xylene vapour. The obtained results indicate that, under the biofilter productivity of $50 \mathrm{~g} / \mathrm{m}^{3} / \mathrm{h}$, treatment efficiency makes $80-85 \%$. Wu et al. (2006) studied biofilter treatment efficiency under the device productivity

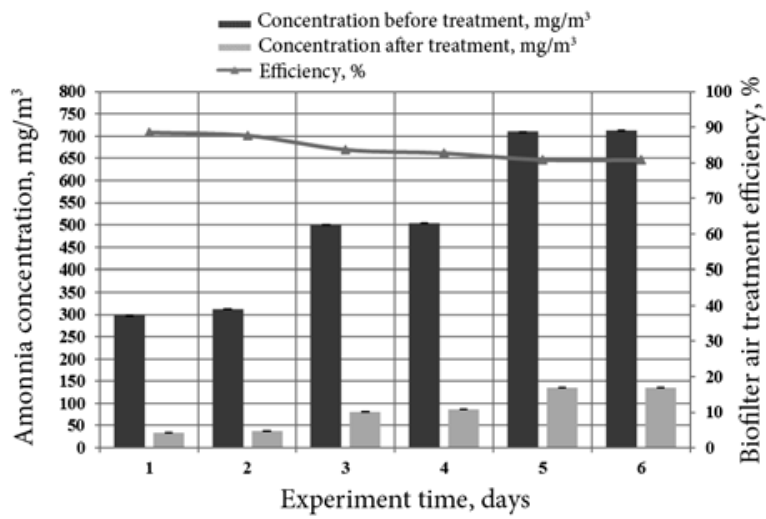

Fig. 7. Ammonia concentration before and after treatment $\left(\mathrm{mg} / \mathrm{m}^{3}\right)$ and the efficiency of biofilter treatment under the application of wavy lamellar plates and the packing material made of wood fiber and not-woven caulking material

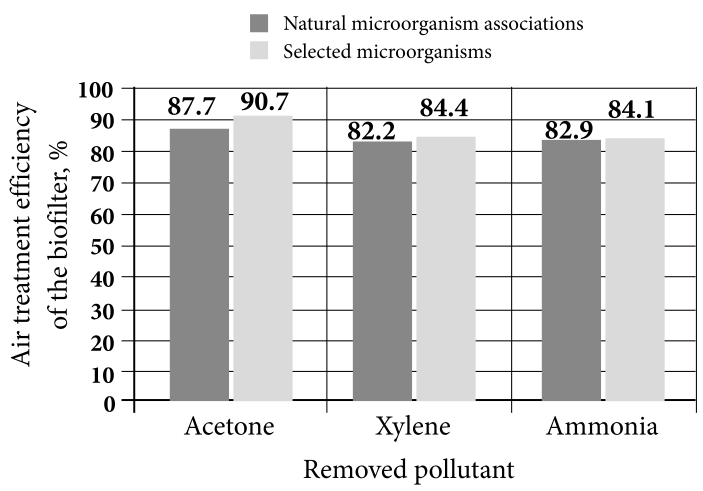

Fig. 8. A comparison of the air treatment efficiency of the biofilter using natural microorganisms and selected microorganisms of the same $50 \mathrm{~g} / \mathrm{m}^{3} / \mathrm{h}$ and found out that the biodestruction process of xylene amounted to $70 \%$. As regards our research, under similar productivity of the biofilter, the efficiency of the biodestruction process makes $83 \%$.

While treating the air contaminated with acetone vapour, the efficiency of the biodestruction process was higher than that in the case of xylene vapour. This could be determined by a lower coefficient of gas solubility in water. The dependence of gas solubility in the bio-medium is determined by Henry's Law (Miller, Allen 2005) which provides that, "at a constant temperature, the amount of a given gas that dissolves in a given type and volume of liquid is directly proportional to the partial pressure of that gas in equilibrium with that liquid". Thus, an increase in temperature decreases gas solubility in the medium while a decrease increases it (Miller, Allen 2004).

Figure 7 displays ammonia concentration in the air supplied to and removed from the device and the dependence of air treatment efficiency on time considering the air flow rate in the packing material $(0.079 \mathrm{~m} / \mathrm{s})$. The research was carried out under the treated air flow making $1.1 \mathrm{l} / \mathrm{s}$. Time for contact between the biopacking material and polluted air was $11.42 \mathrm{~s}$.

Figure 7 also shows that the treatment efficiency of the ammonia biodestruction process, in all days of investigation, similarly to xylene, reached more than $80 \%$. The air treatment efficiency of the biofilter, under $300 \mathrm{mg} / \mathrm{m}^{3}$ ( $1^{\text {st }}$ day of research), in the concentration of ammonia vapour got to $88.1 \%$, the one under $500 \mathrm{mg} / \mathrm{m}^{3}$ ( $3^{\text {rd }}$ day of research $)-83.3 \%$ and that of $700 \mathrm{mg} / \mathrm{m}^{3}\left(6^{\text {th }}\right.$ day of research) $-80.9 \%$.

The tendency towards the efficiency of removing ammonia from air, like xylene, remained similar - an increase in the concentration of ammonia in the supplied air resulted in a gradual decrease of $4-5 \%$ in the efficiency of taking away the pollutant. This influenced a reduction in microorganisms in the packing material. At the beginning of research, the average amount of bacteria was $(7.8 \pm 1.0) \times 10^{8} \mathrm{cfu} / \mathrm{cm}^{2}$, yeast $-(2.6 \pm 0.1) \times 10^{7} \mathrm{cfu} / \mathrm{cm}^{2}$ and micromycetes $-(5.6 \pm 0.9) \times 10^{6} \mathrm{cfu} / \mathrm{cm}^{2}$, whereas at the end of research $\left(6^{\text {th }}\right.$ day $)-(1.6 \pm 0.2) \times 10^{8} \mathrm{cfu} / \mathrm{cm}^{2}$, yeast - $(6.1 \pm 0.2) \times 10^{6} \mathrm{cfu} / \mathrm{cm}^{2}$ and micromycetes $(2.4 \pm 0.2) \times 10^{5} \mathrm{cfu} / \mathrm{cm}^{2}$. The biopacking material contained the largest established amount of bacteria and the smallest amount of micromycetes.

Figure 8 shows the use of the natural microorganism associations multiplied naturally on the biopacking material from ambient air, which is the reason for achieving a lower air treatment efficiency of the biofilter.

While conducting experimental investigations into wavy lamellar plates and using the packing material made of not-woven caulking material and wood fiber, both the self-propagated and selected microorganisms survived under the same maintained conditions: the average humidity 
was from 70 to $80 \%$, the humidity of the packing material made $60-65 \%$, air temperature reached $26-28^{\circ} \mathrm{C}$ and air flow rate $-0.08 \mathrm{~m} / \mathrm{s}$. Contact time for the bio-medium remained the same thus making $11.25 \mathrm{~s}, \mathrm{pH}$ index varied between 7.2 and 7.3 and the temperature of the medium was $30 \pm 1^{\circ} \mathrm{C}$. Thus, it can be accepted that the conditions for the development of the self-propagated and selected microorganisms were favourable enough, and therefore the findings of the performed research can be compared with each other.

The presented (Fig. 8) demonstrates that, along the entire investigation, the air treatment efficiency of the biofilter was more than $80 \%$. The conducted research also found that the highest air treatment efficiency was observed using the selected microorganisms, and while treating the air contaminated with acetone vapour, it reached $90.7 \%$. Study on air treatment efficiency under conditions when natural microorganism associations grew and multiplied on the biopacking material suggest the efficiency of $87.7 \%$. Next to acetone, the air contaminated with xylene vapour was supplied to the biofilter, and air treatment efficiency was higher employing the selected microorganisms (84.4\%) rather than in the case of the self-propagated ones $(82.2 \%)$. The research on xylene and supplying the air contaminated with ammonia to the biofilter highlight the same tendency displaying higher air treatment efficiency under the use of the selected microorganisms, which made $84.1 \%$, i.e. $1.2 \%$ more than the application of natural microorganism associations.

The species composition of microorganisms also has an impact on the air treatment efficiency of the biofilter. The efficiency of using the microorganisms selected and self-propagated on the packing material is higher, as the microorganisms themselves have been specially selected so that to adopt them to the biopacking material and to the three types of pollutants supplied to the biofilter. Thus, the conducted experimental investigation into air treatment has shown that air treatment efficiency, yet at the beginning of the experiment, reaches approximately $50 \%$, whereas as regards natural microorganism associations, it makes only $50 \%$. In the latter case, various species of the natural microorganism associations multiply on the biopacking material; however, only those able to adapt to the contaminant supplied to the biofilter and to its concentration survive.

The advantage of using the selected microorganisms for removing pollutants from the supplied air is that large concentrations of polluted vapours can be supplied to the biofilter, because the selected microorganisms unlike the self-propagated ones do not require adaptation, and therefore air treatment efficiency is higher.

The conducted research has demonstrated that acetone and ammonia rather than xylene are best removed from the contaminated air. This is due to the fact that acetone and ammonia are highly soluble in water, whereas xylene is not. For their growth, microorganisms on the biopacking material absorb airborne pollutants through water. Therefore, microorganisms easier absorb ammonia and acetone rather than xylene, which allows making a conclusion that the higher is the solubility of the pollutant in water, the greater is treatment efficiency.

\section{Conclusions}

The conducted research has shown that the use of the capillary system for the humidification of the packing material made of porous polymer wavy lamellar plates with wood fiber and not-woven caulking material results in the air treatment efficiency of the biofilter, which is more than $80 \%$.

The performed investigation demonstrates that the highest air treatment efficiency has been achieved employing the selected microorganisms. While treating the air contaminated with acetone vapour, efficiency reached $90.7 \%$, xylene made $84.4 \%$ and ammonia $-84.1 \%$. The average use of the selected microorganisms points to air treatment efficiency which is $2.4 \%$ higher than that employing natural microorganism associations.

Experimental investigation into the selected microorganisms applied for air treatment has revealed that air treatment efficiency, yet at the beginning of research, achieves about $50 \%$, whereas in the case of the self-propagated ones, only $50 \%$ can be observed. In the latter case, various species of natural microorganism associations multiply on the biopacking material; however, only those able to adapt to the contaminant supplied to the biofilter and to its concentration survive.

The carried out research has established that acetone and ammonia rather than xylene are best removed from the contaminated air. This is due to the fact that acetone and ammonia are highly soluble in water, whereas xylene is not.

Bacteria - $(1.0 \pm 0.2) \times 10^{10} \mathrm{cfu} / \mathrm{cm}^{2}$, yeast $-(6.1 \pm$ $0.2) \times 10^{6} \mathrm{cfu} / \mathrm{cm}^{2}$ and micromycetes $-(3.2 \pm 0.6) \times 10^{7} \mathrm{cfu} / \mathrm{cm}^{2}$ are among the cultures most frequently found between the selected microorganisms of the biopacking material.

\section{Acknowledgements}

The research has been carried out within the framework of the project Applied research and technological development of plate type air treatment biofilter with a capillary humidification system for packing material "BIOFILTER" (Project No. VP1-3.1-ŠMM-10-V-02-015) under the Operational Programme for the Development of Human Resources 2007-2013, priority axis 3 "Strengthening researchers abilities", measure VP1-3.1-ŠMM-10-V "Promotion of high level international research". The project has been funded by the European Social Fund, supported and cofunded by the European Union and the Republic of Lithuania. The beginning of project implementation was 
on 1 February 2013. Total duration of the project is 24 months. The aim of the project is high-level international research implementation in order to create a more efficient model of the plate type air treatment biofilter with a capillary humidification system for the packing material. The research was performed employing the facilities of the Open Access Centre of the Joint Nature Research Centre.

\section{References}

Baltrenas, P.; Zagorskis, A. 2010. Investigation into the air treatment efficiency of biofilters of different structures, Journal of Environmental Engineering and Landscape Management 18: 23-31. http://dx.doi.org/10.3846/jeelm.2010.03

Baltrenas, P.; Zagorskis, A. 2009. Investigation of cleaning efficiency of a biofilter with an aeration chamber, Journal of Environmental Engineering and Landscape Management 17: 12-19. http://dx.doi.org/10.3846/1648-6897.2009.17.12-19

Baltrènas, P.; Zigmontiene, A.; Vaiškūnaite, R. 2004. Oro valymo biotechnologijos [Biotechnology of air purification], Vilnius: Technika. 205 p.

Beyaz, S.; Darkrim Lamari, F.; Weinberger, B.; Langlois, P. 2010. Nanoscale carbon material porosity effect on gas adsorption, International Journal of Hydrogen Energy 35(1): 217-224. http://dx.doi.org/10.1016/j.ijhydene.2009.10.007

Boswell, J. 2010. Understanding biofilters, Pollution Engineering 42(2): 14-18.

Chang, K; Lu, C. 2003. Biofiltration of isopropyl alcohol and acetone mixtures by a trickle-bed air biofilter, Process Biochemistry 39: 415-423.

http://dx.doi.org/10.1016/S0032-9592(03)00096-7

Chaverri, P.; Samuels, G. J. 2003. Hypocrea Trichoderma (Ascomycota, Hypocreales, Hypocreaceae): species with green ascospores, Studies in Mycology 48: 1-119.

Delhomenie, M.; Heitz, M. 2005. Biofiltration of air: a review, Critical Reviews in Biotechnology 25: 53-72. http://dx.doi.org/10.1080/07388550590935814

Domsh, K. H.; Gams, W.; Anderson, T. H. 2007. Compendium of soil micromicetes, 2 nd ed., taxonomically revised by W. Gams. Eching: IHW-Verlag. 672 p.

Dorado, A. D.; Baquerizo, G.; Maestre, J. P.; Gamisans, X.; Gabriel, D.; Lafuente, J. 2008. Modeling of a bacterial and fungal biofilter applied to toluene abatement: kinetic parameters estimation and model validation, Chemical Engineering Journal 140(1-3): 52-61. http://dx.doi.org/10.1016/j.cej.2007.09.004

Eldon, R.; Murthy, D. V. S.; Swaminathan, T. 2010. Effect of flow rate, concentration and transient-state operations on the performance of a biofilter treating xylene vapors, Journal of Water, Air \& Soil Pollution 211(1-4): 79-93.

Garrity, G. M.; Bell, J. A.; Lilburn, T. 2005. Order VI. Legionellales ord. nov., in D. J. Brenner, N. R. Krieg, J. T. Staley (Eds.). Bergey's manual of systematic bacteriology, 2nd ed., vol. 2: The Proteobacteria, part B: The Gammaproteobacteria. Springer. $210 \mathrm{p}$.

Jeong, E.; Hirai, M.; Shoda, M. 2006. Removal of $p$-xylene with pseudomonas sp. NBM21 in biofilter, Journal of Bioscience and Bioengineering 102(4): 281-287.

http://dx.doi.org/10.1263/jbb.102.281
Jeong, E.; Hirai, M.; Shoda, M. 2008. Removal of $o$-xylene using biofilter inoculated with Rhodococcus sp. BTO62, Journal of Hazardous Materials 152(1): 140-147. http://dx.doi.org/10.1016/j.jhazmat.2007.06.078

Jun, Y.; Wenfeng, X. 2009. Ammonia biofiltration and community analysis of ammonia-oxidizing bacteria in biofilters, Bioresource Technology 100(17): 3869-3876. http://dx.doi.org/10.1016/j.biortech.2009.03.021

Liao, Q.; Tian, X.; Chen, R.; Zhu, X. 2008. Mathematical model for gas-liquid two-phase flow and biodegradation of a low concentration volatile organic compound (VOC) in a trickling biofilter, International Journal of Heat and Mass Transfer 51(7-8): 1780-1792. http://dx.doi.org/10.1016/j.ijheatmasstransfer.2007.07.007

LST EN ISO 10523: 2012. Water quality - Determination of $p H$. Lietuvos standartizacijos departamentas.

Mansour, H. B.; Ghedira, K.; Barillier, D.; Ghedira, L. C.; Mosrati, R. 2011. Degradation and detoxification of acid orange 52 by Pseudomonas putida mt-2: a laboratory study, Environmental Science and Pollution Research 18(9): 1527-1535. http://dx.doi.org/10.1007/s11356-011-0511-7

Miller, M. J.; Allen, D. G. 2004. Transport of hydrophobic pollutants through biofilms in biofilters, Chemical Engineering Science 59: 3515-3525. http://dx.doi.org/10.1016/j.ces.2004.05.011

Miller, M. J.; Allen, D. G. 2005. Biodegradation of $\alpha$-pinene in model biofilms in biofilters, Environmental Science \& Technology 39(15): 5856-5863. http://dx.doi.org/10.1021/es048254y

Mohseni, M.; Allen, D. G. 2000. Biofiltration of mixtures of hydrophilic and hydrophobic volatile organic compounds, Chemical Engineering Science 55: 1545-1558. http://dx.doi.org/10.1016/S0009-2509(99)00420-0

Palleroni, N. J. 1984. Genus I. Pseudomonas Migula 1984, 237AL, in N. R. Krieg, J. G. Holt (Eds.). Bergey's manual of systematic bacteriology, vol. 1, 141-199. Baltimore: Williams \& Wilkins.

Paulauskienè, T.; Zabukas, P.; Vaitiekūnas, P.; Žukauskaitė, A.; Kvedaras, V. 2011. Investigation of volatile organic compound (VOC) emission beyond the territory of oil terminals during different seasons, Journal of Environmental Engineering and Landscape Management 19(1): 44-52. http://dx.doi.org/10.3846/16486897.2011.558994

Pečiulytė, D.; Bridžiuvienè, D. 2008. Lietuvos grybai. II tomas. Skurdeniečiai ir pelessiečiai. Botanikos institutas, Vilnius. $264 \mathrm{p}$

Pielech-Przybylska, K.; Ziemiński, K.; Szopa, J. S. 2006. Acetone biodegradation in a trickle-bed biofilter, International Biodeterioration \& Biodegradation 57(4): 200-206. http://dx.doi.org/10.1016/j.ibiod.2005.12.005

Samson, R. A.; Frisvad, J. 2004. Polyphasic taxonomy of Penicillium subgenus Penicillium. A guide to identification of food and air-borne terverticillate Penicillia and their mycotoxins, Studies in Mycology 49: 1-174.

Shareefdeen, Z.; Herner, B.; Webb, D.; Wilson, S. 2003. Biofiltration eliminates nuisance chemical odors from industrial air streams, Journal of Industrial Microbiology and Biotechnology 30: $168-174$

Trejo-Aguilar, G.; Revah, S.; Lobo-Oehmichen, R. 2005. Hydrodynamic characterization of a trickle bed air biofilter, Chemical Engineering Journal 113(2-3): 145-152. http://dx.doi.org/10.1016/j.cej.2005.04.001 
Wright, W. F. 2005. Transient response of vapor-phase biofilters, Chemical Engineering Journal 113(2-3): 161-173. http://dx.doi.org/10.1016/j.cej.2005.04.009

Wu, D.; Quan, X.; Zhao, Y.; Chen, S. 2006. Removal of p-xylene from an air stream in a hybrid biofilter, Journal of Hazardous Materials 136(2): 288-295.

http://dx.doi.org/10.1016/j.jhazmat.2005.12.017

Yang, C.; Chen, H.; Zeng, G.; Yu, G.; Luo, S. 2010. Biomass accumulation and control strategies in gas biofiltration, Biotechnology Advances 28(4): 531-540.

http://dx.doi.org/10.1016/j.biotechadv.2010.04.002
Zigmontienè, A.; Baltrènas, P. 2004. Biological purification of air polluted with volatile organic compounds by using active sludge recirculation, Journal of environmental engineering and landscape management 12(2): 45-52.

Zigmontienè, A.; Žarnauskas, L. 2011. Investigation and analysis of air-cleaning biofilter hybrid biocharge quantitative and qualitative parameters, Journal of Environmental Engineering and Landscape Management 19(1): 81-88. http://dx.doi.org/10.3846/16486897.2011.557472

Kęstutis MAČAITIS. Bachelor of Science (Roads and Railways) from VGTU (2011). Master of Environmental and Climate Engineering from the Department of Environmental Engineering, Vilnius Gediminas Technical University (VGTU), 2013. Publications: the author of 3 research papers. Research interests: air pollution, electromagnetic fields, waste management technologies, physical pollution.

Antonas MISEVIČIUS. Bachelor of Science (Environmental Engineering) from VGTU (2009). Research interests: Master of Environmental Management and Cleaner Production from the Department of Environmental Engineering, Vilnius Gediminas Technical University (VGTU), 2011. Publications: the author of 5 research papers. Research interests: waste management technologies, waste management, recycling, air pollution.

Algimantas PAŠKEVICIUS. Head of the Laboratory of Biodeterioration Research at the Institute of Botany of Nature Research Centre, Doctor of Science (Biomedicine Sciences). 110 scientific publications, 6 invention patents. Research interests: fungal physiology and biochemistry, epidemiology and biology of pathogenic micromycetes, biotechnologies.

Vita RAUDONIENĖ. Dr, Researcher at the Laboratory of Biodeterioration Research at the Institute of Botany of Nature Research Centre. 36 scientific publications. Main fields of scientific investigation: microscopic micromycetes under various ecological conditions and their ecological and physiological peculiarities, the effect of ecological factors on the activity of microorganisms, significance of micromycetes for the degradation of the plant remnant in the lignin-cellulose complex.

Jüratė REPEČKIENĖ. Dr, Researcher at the Laboratory of Biodeterioration Research at the Institute of Botany of Nature Research Centre. 71 scientific publications. Main fields of scientific investigation: relationship of micromycetes and bacteria population in soil and their physiological peculiarities. Scientific research interests include the ability of microorganisms to degrade different waste and pollutant and to produce secondary metabolites. 